\title{
The quality of carrot (Daucus carota L.) cultivated in the field depending on iodine and selenium fertilization
}

\author{
Sylwester Smoleńn ${ }^{1 *}$, Lukasz Skoczylas ${ }^{2}$, Iwona Ledwożyw-Smoleńn ${ }^{3}$ Roksana Rakoczy', \\ Marta Liszka-Skoczylas ${ }^{4}$, Aneta Kopeć5 ${ }^{5}$, Ewa Piątkowska ${ }^{5}$, Renata Bieżanowska-Kopeć5, \\ Aneta Koronowicz, Joanna Kapusta-Duch ${ }^{5}$, Wtodzimierz Sady ${ }^{1}$
}

\begin{abstract}
${ }^{1}$ Unit of Plant Nutrition, Institute of Plant Biology and Biotechnology Faculty of Biotechnology and Horticulture University of Agriculture in Krakow, 29 Listopada 54, 31-425 Kraków, Poland ${ }^{2}$ Department of Fruit, Vegetable and Mushroom Processing, Faculty of Food Technology University of Agriculture in Krakow, Balicka 122, 30-149 Kraków, Poland ${ }^{3}$ Unit of Biochemistry, Institute of Plant Biology and Biotechnology, Faculty of Biotechnology and Horticulture University of Agriculture in Krakow, 29 Listopada 54, 31-425 Kraków, Poland ${ }^{4}$ Department of Engineering and Machinery in the Food Industry, Faculty of Food Technology University of Agriculture in Krakow, Balicka 122, 30-149 Kraków, Poland

${ }^{5}$ Department of Human Nutrition, Faculty of Food Technology University of Agriculture in Krakow, Balicka 122, 30-149 Kraków, Poland
\end{abstract}

\begin{abstract}
The aim of the study was to evaluate the influence of various chemical forms of iodine $\left(\mathrm{I}^{-}\right.$and $\left.\mathrm{IO}_{3}{ }^{-}\right)$and selenium $\left(\mathrm{SeO}_{3}^{2-}\right.$ and $\mathrm{SeO}_{4}^{2-}$ ) on the nutritional and health-promoting quality of carrot (Daucus carota L.) storage roots. The experiment (conducted in 2012-2014) comprised the soil fertilization of carrot 'Kazan' $\mathrm{F}_{1}$ in the following combinations: 1. Control, 2. KI, 3. $\mathrm{KIO}_{3}, 4 . \mathrm{Na}_{2} \mathrm{SeO}_{4}, 5 . \mathrm{Na}_{2} \mathrm{SeO}_{3}, 6 . \mathrm{KI}+\mathrm{Na}_{2} \mathrm{SeO}_{4}, 7 . \mathrm{KIO}_{3}$ $+\mathrm{Na}_{2} \mathrm{SeO}_{4}, 8 . \mathrm{KI}+\mathrm{Na}_{2} \mathrm{SeO}_{3}, 9 . \mathrm{KIO}_{3}+\mathrm{Na}_{2} \mathrm{SeO}_{3}$. Iodine and selenium were applied twice: before sowing and as top dressing in a total dose of $5 \mathrm{~kg} \mathrm{I} \mathrm{ha}^{-1}$ and $1 \mathrm{~kg} \mathrm{Se} \mathrm{ha}^{-1}$. No significant influence of iodine and selenium fertilization was noted with respect to average root weight and leaf yield. Each year, the application of KI + $\mathrm{Na}_{2} \mathrm{SeO}_{4}$ negatively affected the content of glucose and total sugars in carrot. An increased sucrose level was noted in the roots of plants treated with $\mathrm{KIO}_{3}+\mathrm{Na}_{2} \mathrm{SeO}_{4}$, with a total sugar concentration comparable to the control. Irrespective of the year, carrots fertilized with KI were characterized by the highest accumulation of nitrates (III) $-\mathrm{NO}_{2}^{-}$in roots. The simultaneous introduction of iodine and selenium compounds (KI + $\mathrm{Na}_{2} \mathrm{SeO}_{4}, \mathrm{KIO}_{3}+\mathrm{Na}_{2} \mathrm{SeO}_{4}, \mathrm{KI}+\mathrm{Na}_{2} \mathrm{SeO}_{3}$ and $\mathrm{KIO}_{3}+\mathrm{Na}_{2} \mathrm{SeO}_{3}$ ) into the soil reduced the content of nitrates (III) in carrot as compared to combinations with the individual application of these compounds. The influence of the tested factors on other analysed parameters (the content of dry weight, nitrates (V), chlorides, oxalates, citrates, free amino acids, carotenoids, phenolic compounds, phenylpropanoids, flavonols and anthocyanins as well as free radical scavenging activity (DPPH) was rather year-dependent.
\end{abstract}

Key words: biofortification, carotenoids, citrates, DPPH, oxalates, phenolic compounds, sugars

\section{Abbreviations:}

GS-GOGAT - glutamine synthetase-glutamate synthase; NiR - nitrite reductase; NR - nitrate reductase; PAR - photosynthetically active radiation; SeMet - selenomethionine; SeCys - selenocysteine 


\section{INTRODUCTION}

Carrot is one of the most popular crop species both in Poland and worldwide and its nutritional and health-promoting quality is of great importance, particularly with respect to the production of baby food (Cebulak and Sady 2000, Rożek et al. 2000, Sady and Cebulak 2000).

The biofortification (enrichment) of crop plants with mineral nutrients ( $\mathrm{Fe}, \mathrm{Zn}, \mathrm{Se}, \mathrm{I}, \mathrm{Mg}, \mathrm{Ca}$ ) is one of the low-cost but effective methods of their introduction into the food chain. It is particularly recommended for areas with substantial deficiency of micronutrients in soils (White and Broadley 2009, Przybysz et al. 2016).

Selenium and iodine are not essential nutrients for plants - yet selenium is included in the group of beneficial elements (Kopsell and Kopsell 2007, Kabata-Pendias 2011). However, both elements play important roles in human and animal organisms. A common situation is an occurrence of a simultaneous deficiency or hidden hunger for iodine and selenium in numerous regions of the world (White and Broadley 2009).

Many studies have documented the possibility of increasing the accumulation of iodine (Blasco et al. 2010, Kato et al. 2013, Lawson et al. 2015) and selenium in plants (Ríos et al. 2010, HawrylakNowak et al. 2015). However, the problem of simultaneous plant fertilization with these elements has not been often described. Such an approach requires the development of optimal agro-technical rules for conducting double biofortification of crop plants with iodine and selenium.

So far, studies on the simultaneous application of iodine and selenium have mainly been conducted in soilless and hydroponic systems with the cultivation of spinach (Zhu et al. 2004) or lettuce (Smoleń et al. 2014 a). In field conditions, a single one-year experiment was carried out with the application of $\mathrm{Se}+\mathrm{Zn}+\mathrm{I}$ fertilization during the cultivation of wheat, maize, soybean, potato, canola and cabbage (Mao et al. 2014). The above-mentioned works document solely the efficiency of biofortification, i.e. improved uptake and accumulation of iodine and selenium by crop plants, but lack the description of the effect of its increased content on the nutritional and health-promoting quality of biofortified crops. Only Smoleń et al. (2014a) have presented the spectrum of effects exerted by the simultaneous application of I and $\mathrm{Se}$ - foliarly or through the nutrient medium - on the uptake and accumulation of macro- and micronutrients by lettuce plants. Double iodine and selenium biofortification of carrot plants has not yet been studied, therefore, no information is available as to whether this process is even possible. Conducting such studies may help to fill the information gap with respect to the influence of iodine and selenium application on the nutritional quality of carrot storage roots. It is all the more important as the soil application of iodine alone (also when combined with nitrogen fertilization) diversely changes the nutritional and health-promoting quality of carrot roots. It also affects the tested parameters after storage (Smolen et al. 2014b).

Iodine and selenium uptake activates the metabolic processes responsible for the conversion of these elements into organic compounds, including the biosynthesis of seleno-amino acids: selenomethionine (SeMet) and selenocysteine (SeCys) (Zhu et al. 2009, Winkel at al. 2015, Longchamp et al. 2015), iodine-containing proteins (Kabata-Pendias 2011) or the emission of volatile iodine $\left(\mathrm{CH}_{3} \mathrm{I}-\mathrm{Rhew}\right.$ et al. 2003) or selenium compounds: dimethyl selenide (DMSe) and dimethyl diselenide (DMDSe) (Zhu et al. 2009, Winkel et al. 2015). All of these processes require a substantial input of energy and may impair the production and accumulation of sugars or secondary metabolites, including those responsible for organoleptic, nutritional and health-promoting values (nutraceuticals). In the case of carrot storage roots, the following parameters should be taken into account: the content of sugars (fructose, glucose, sucrose, total soluble sugars), free amino acids, carotenoids, phenolic compounds as well as free radical scavenging activity (Barańska et al. 2005, 2006, Quilitzsch et al. 2005, Barański et al. 2012, Smoleń et al. 2014b).

The research hypothesis stated that conducting simultaneous fertilization with iodine and selenium would allow us to obtain a carrot yield with improved or unchanged quality. The aim of the study was to evaluate the influence of soil fertilization with various chemical forms of iodine $\left(\mathrm{I}^{-}\right.$and $\left.\mathrm{IO}_{3}{ }^{-}\right)$and selenium $\left(\mathrm{SeO}_{3}{ }^{2-}\right.$ and $\left.\mathrm{SeO}_{4}{ }^{2-}\right)$ on the nutritional and health-promoting qualities of storage roots of carrot (Daucus carota L.)

\section{MATERIAL AND METHODS}

\section{Plant material and treatments}

In the years 2012-2014, the field cultivation of carrot (Daucus carota L.) cultivar Kazan $\mathrm{F}_{1}$ was conducted in Marszowice (50 $\left.{ }^{\circ} 18^{\prime} 6 \mathrm{~N}, 20^{\circ} 09^{\prime} 1 \mathrm{E}\right)$ near Krakow, Poland. Each year, carrot was grown 
Table 1. Selected physical and chemical properties of the $0-30 \mathrm{~cm}$ soil layer prior to the experiment in $2012-2014$ $(n=4)$

\begin{tabular}{lccc}
\hline Parameter & 2012 & 2013 & 2014 \\
\hline $\mathrm{pH}_{\mathrm{H}_{2} \mathrm{O}}$ & 6.30 & 7.77 & 6.10 \\
$\mathrm{EC}\left(\mathrm{mS} \mathrm{cm}{ }^{-1}\right)$ & 0.13 & 0.12 & 0.04 \\
$\mathrm{Eh}(\mathrm{mV})$ & +220.0 & +257.9 & +233.5 \\
Organic matter (\%) & 2.11 & 2.48 & 2.25 \\
Particle size fraction (in \%): & $4 / 47 / 49$ & $2 / 48 / 50$ & $4 / 47 / 49$ \\
sand / silt / loam & $\begin{array}{c}\text { Silty clay } \\
\text { (heavy soil) }\end{array}$ & $\begin{array}{c}\text { Silty clay } \\
\text { (heavy soil) }\end{array}$ & $\begin{array}{c}\text { Silty clay } \\
\text { (heavy soil) }\end{array}$ \\
Soil texture class & & & \\
\hline
\end{tabular}

on the same farm but on different sites within a single soil complex.

Carrot was cultivated on heavy soil of a silty clay type, with a comparable content of main soil separates within the years 2012-2014 (Tab. 1). The chemical properties of the soil in the subsequent years are presented in Table 1.

The study included soil fertilization with iodine and selenium in the following combinations: 1. Control, 2. KI, 3. $\mathrm{KIO}_{3}, 4 . \mathrm{Na}_{2} \mathrm{SeO}_{4}, 5 . \mathrm{Na}_{2} \mathrm{SeO}_{3}$, 6. $\mathrm{KI}+\mathrm{Na}_{2} \mathrm{SeO}_{4}, 7 . \mathrm{KIO}_{3}+\mathrm{Na}_{2} \mathrm{SeO}_{4}, 8 . \mathrm{KI}+$ $\mathrm{Na}_{2} \mathrm{SeO}_{3}, 9 . \mathrm{KIO}_{3}+\mathrm{Na}_{2} \mathrm{SeO}_{3}$. Iodine and selenium were applied twice: prior to seed sowing (before ridge formation) and as top-dressing (at canopy closure), each at a dose of $2.5 \mathrm{~kg} \mathrm{I} \mathrm{ha}^{-1}+0.5 \mathrm{~kg}$ Se $\mathrm{ha}^{-1}$. Pre-sowing fertilization with iodine and selenium was conducted in the third 10-day period of April (12 April 2012, 18 April 2013 and 04 April 2014), and as top-dressing in the third 10-day period of June (29 June 2012, 3 July 2013 and 4 July 2014). The total amount of iodine and selenium introduced into the soil was $5 \mathrm{~kg} \mathrm{I} \mathrm{ha}^{-1}$ and $1 \mathrm{~kg} \mathrm{Se} \mathrm{ha-1}$, respectively. Iodine and selenium were applied as $\mathrm{KI}$ and $\mathrm{KIO}_{3}$ (Avantor Performance Materials, Poland) as well as $\mathrm{Na}_{2} \mathrm{SeO}_{4}$ and $\mathrm{Na}_{2} \mathrm{SeO}_{3}$ (Sigma-Aldrich, Germany); all compounds were of analytical grade. The experiment was arranged in a split-plot design. Each treatment was randomized in four repetitions on $4 \mathrm{~m} \times 6 \mathrm{~m}\left(24 \mathrm{~m}^{2}\right)$ plots. The total area of the experiment was $864 \mathrm{~m}^{2}$.

Based on the results of the soil chemical analysis, $\mathrm{N}$, P and $\mathrm{K}$ fertilization was conducted (along with iodine and selenium application) one day prior to ridge formation in order to supplement nutrient contents to the level optimal for carrot: N-100, P-80 and $\mathrm{K}-200$ (in $\mathrm{mg} \mathrm{dm}^{-3}$ of soil). Nitrogen was applied as urea, phosphorus as ammonium phosphate, and potassium as $60 \%$ potassium salt.

Carrots were cultivated in single rows on 40 $\mathrm{cm}$-wide and $30 \mathrm{~cm}$-high ridges at a seeding rate of 37 seeds $\mathrm{m}^{-1}$ (approximately 600,000 seeds per hectare). The seeds were sown on 19 April 2012, 25 April 2013 and 05 April 2014. Carrot roots were harvested on 26 September 2012, 11 September 2013 and 9 September 2014. During harvest, the yield of carrot leaves and storage roots as well as plant density per hectare were determined (detailed data is presented in the publication by Smolen et al. 2016a). Based on these measurements, the average leaf yield per plant as well as the average weight of the roots were calculated.

At harvest, samples of approximately $10 \mathrm{~kg}$ of carrot storage roots were chosen from each of the four plots (replications) for laboratory analysis.

\section{Plant analysis}

Dry matter content in carrot storage roots was assayed at $105^{\circ} \mathrm{C}$. The total content of carotenoids in fresh carrot roots was analysed using a $\beta$-carotene standard curve after sample extraction with acetone/ $\mathrm{n}$-hexane $(4: 6 ; \mathrm{v} / \mathrm{v})$. The determination of phenols, phenylpropanoids, flavonols and anthocyanins in carrot was conducted in $80 \%$ methanol extracts using the spectrophotometric method described by Fakumoto and Mazza (2000). Free radical scavenging activity of the prepared plant extracts was evaluated on the basis of sample reaction with diphenylpicrylhydrazyl (DPPH) (Pekkarinen et al. 1999).

The content of free amino acids, sucrose, glucose and fructose was assessed in ethanol-preserved samples. The level of free amino acids was determined spectrophotometrically after a reaction with ninhydrin. The contents of sucrose, glucose and fructose were analysed using RP-HPLC. The assessment of the level of these compounds was conducted in room temperature using a Knauer system (Germany). Samples $(10 \mu \mathrm{l})$ were injected into an amine LiChrospher RP 100-10 $\mathrm{NH}_{2} 250$ $\times 4 \mathrm{~mm}$ column. The eluent contained the mixture of acetonitrile/water $(87: 13 \mathrm{v} / \mathrm{v})$ and the flow rate was 
adjusted to $1.3 \mathrm{ml} \mathrm{min}^{-1}$. Detection was conducted using a Smartline RI 2300 refractometric detector (Bogdanov 2002).

The contents of nitrates (V), nitrates (III), chlorides, oxalates and citrates in carrot leaves and roots were analysed using capillary electrophoresis. Plant samples were dried in a dryer with forced air circulation at $70^{\circ} \mathrm{C}$ and ground in a laboratory grinder. Extraction was conducted according to the following procedure: $0.1 \mathrm{~g}$ of air-dried plant samples with $20 \mathrm{ml}$ of extraction solution were put into $30 \mathrm{ml}$ falcon tubes. After mixing, samples were incubated for 1 hour at $90^{\circ} \mathrm{C}$, cooled to a temperature of approximately $20^{\circ} \mathrm{C}$, mixed thoroughly and centrifuged for $15 \mathrm{~min}$ at 4,500 rpm. The supernatants were filtered through a 0.25 $\mu \mathrm{m}$ cellulose acetate membrane filter and analysed using a PA 800 Plus capillary electrophoresis system (Beckman Coulter, USA) with DAD detection. For the measurements, a silica capillary tube with an i.d. of $75 \mu \mathrm{m}$, o.d. of $365 \mu \mathrm{m}$ and a total length of 50 $\mathrm{cm}$ was used. A negative power supply of $-4 \mathrm{kV}$ was applied. The running buffer solution was prepared as proposed by Zhao et al. (2011), containing 30 mmol NaH $\mathrm{PO}_{4}, 15 \mathrm{mmol} \mathrm{Na} \mathrm{B}_{4} \mathrm{O}_{7}$ and $0.2 \mathrm{mmol}$ CTAB (pH 8.80).

\section{Meteorological data}

Each year, carrot was grown from April to September. During that period, the total amount of rainfall was $293.4,428.5$ and $437.9 \mathrm{~mm}$, whereas the mean daily air temperature was $16.1,15.2$ and $15.5^{\circ} \mathrm{C}$ in 2012,2013 and 2014 , respectively (Fig. 1 - data from the HOBO Weather Station). The average daily PAR value during the time from

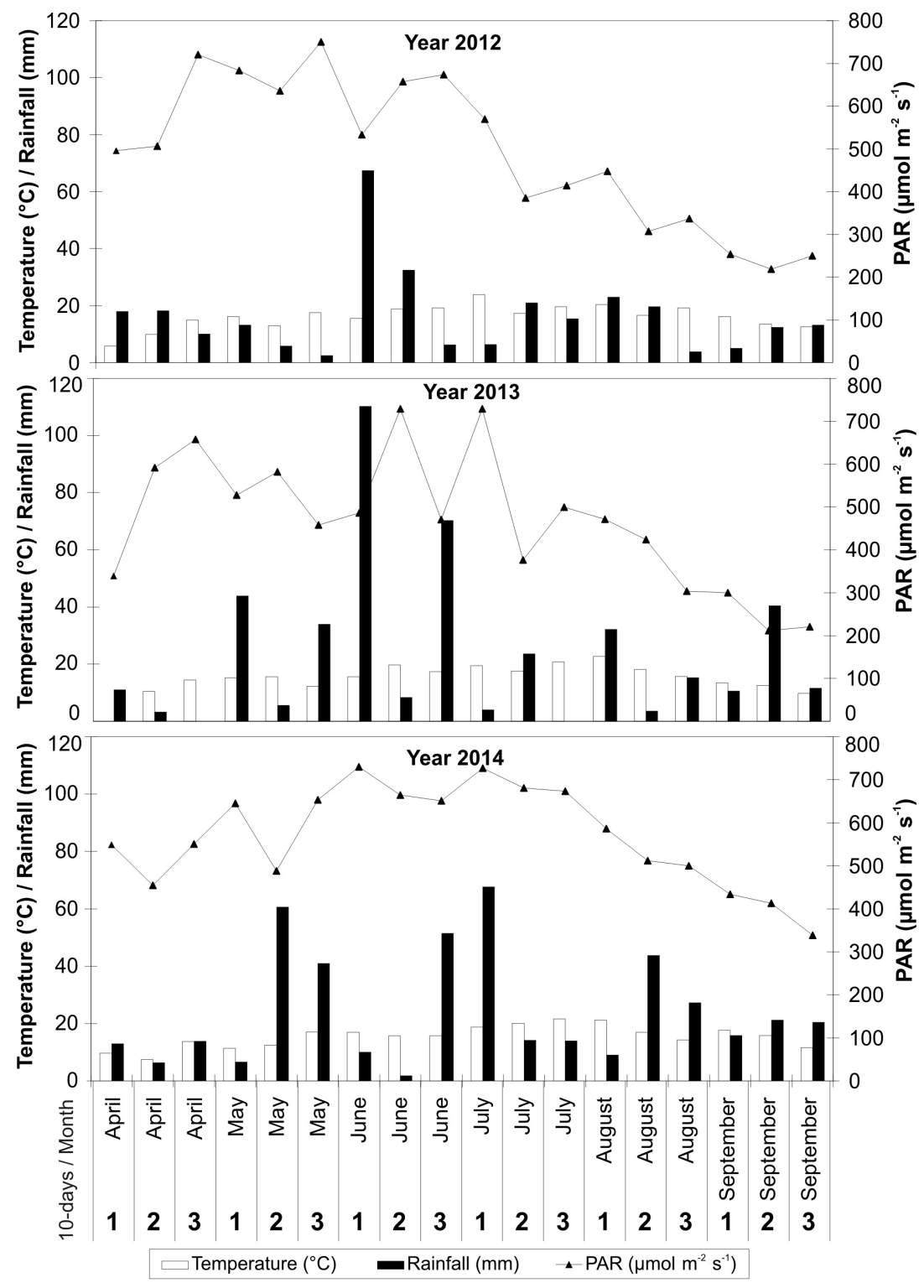

Figure 1. Meteorological data for carrot cultivation in 2012, 2013 and 2014 
carrot planting in the field to the harvest was 491.0, 465.3 and $569.6 \mu \mathrm{mol} \mathrm{m}^{-2} \mathrm{~s}^{-1}$ in 2012, 2013 and 2014, respectively.

In 2012, the most unfavourable conditions with respect to the amount and distribution of rainfall occurred, as compared to the years 2013-2014 (Fig. 1). The total amount of rainfall from April to September 2012 was $141.6 \mathrm{~mm}$ lower, and in the years 2013-2014, it fluctuated around the average for the period of 1971-2000 (435 mm - GUS 2005). From April to September of 2012, a higher mean daily air temperature was recorded than in the same period in 2013 and 2014 it was $1.8^{\circ} \mathrm{C}$ higher than the mean from the years $1971-2000\left(14.3^{\circ} \mathrm{C}\right.$, GUS 2005 ) and was caused by heat spells occurring in the summer months. More precisely, in the years 1971-2000, the average monthly air temperature was $8.0^{\circ} \mathrm{C}$ in April, $13.4^{\circ} \mathrm{C}$ in May, $16.2^{\circ} \mathrm{C}$ in June, $17.8^{\circ} \mathrm{C}$ in July, $17.5^{\circ} \mathrm{C}$ in August and $13.2^{\circ} \mathrm{C}$ in September. In the same period, the average monthly rainfall in the area under study was $50 \mathrm{~mm}$ in April, $74 \mathrm{~mm}$ in May, $94 \mathrm{~mm}$ in June, $81 \mathrm{~mm}$ in July, $76 \mathrm{~mm}$ in August and $60 \mathrm{~mm}$ in September (GUS 2005).

With respect to PAR, its highest total was noted in 2014 and was evenly distributed throughout the entire period of carrot cultivation (Fig. 1). In the years 2012-2013, large fluctuations in PAR values in the subsequent ten-day periods from April to mid-August were recorded.

\section{Data analysis}

All data were subjected to an analysis of variance using the ANOVA module of Statistica 10.0 PL. The Tukey test was used for determining the significance between the means. The significance was declared at $p<0.05$.

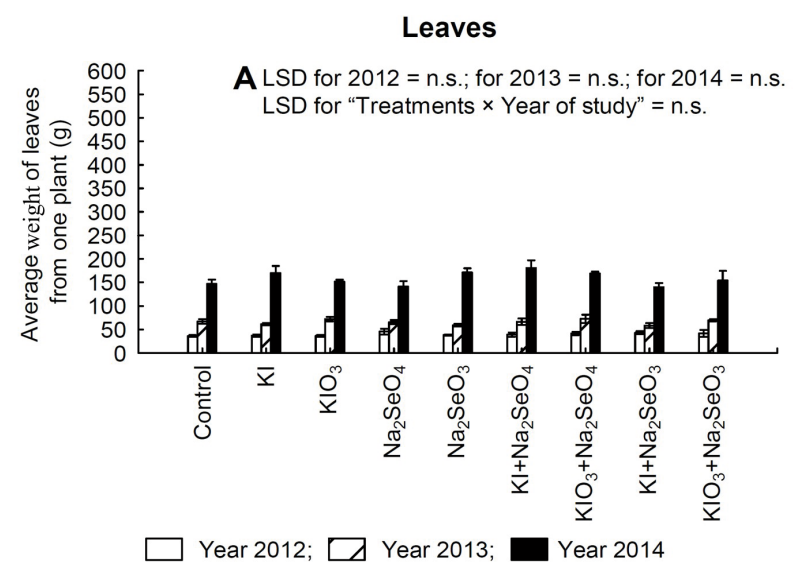

\section{RESULTS AND DISCUSSION}

\section{Biomass}

Despite the diverse weather conditions in 20122014, the tested combinations with iodine and selenium fertilization did not significantly affect the average weight of a single root as well as leaf yield per plant (Fig. 2) in any year of the study.

Generally, the lowest yield of carrot leaves and roots was noted in 2012 due to less favourable weather conditions than those occurring in 20132014 - particularly with respect to the smaller amount of rainfall and higher air temperature. The year 2014 was characterized by the most optimal conditions for carrot cultivation and in that year the highest values of leaf yield and average weight of root were noted.

Detailed data concerning the effects of iodine and selenium fertilization on various parameters of carrot yield (including, among others, biological, total and marketable yield) are presented elsewhere (Smoleń et al. 2016a). In the mentioned study, the results of the level of iodine and selenium accumulation in carrot leaves and storage roots are also included.

Using tested doses of both elements, we did not observe any symptoms of their negative effect on carrot plants even despite the substantial levels of iodine and selenium accumulation in leaves and storage roots (Smolen et al. 2016a). In the other study conducted by our team using the same doses and chemical forms of iodine and selenium, a toxicity of $\mathrm{Na}_{2} \mathrm{SeO}_{4}$ applied alone or together with iodine on lettuce plants was revealed (Smoleń et al. 2015). This may indicate that carrot is a crop species less sensitive than lettuce to high doses of $\mathrm{Na}_{2} \mathrm{SeO}_{4}$ when applied alone or together with iodine. It needs

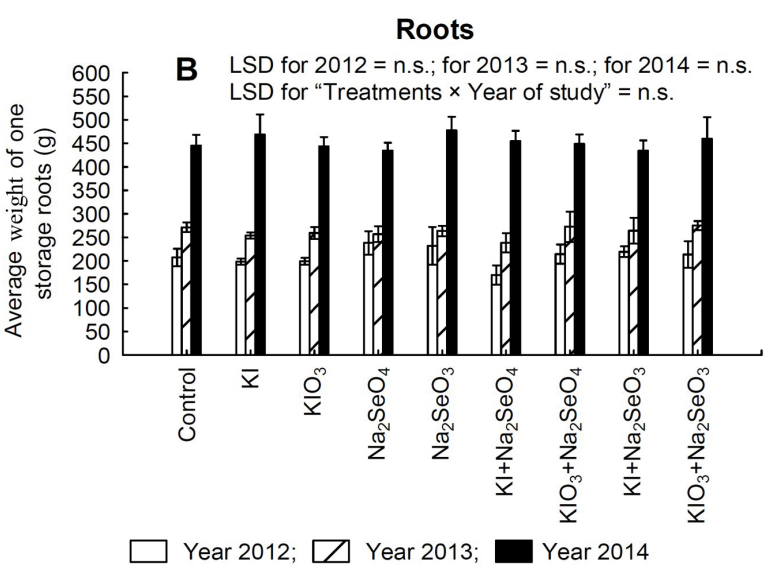

Figure 2. Average weight of leaves per plant (A) and one storage root (B) in each year of the study (2012-2014) depending on the applied I and Se fertilization. Bars indicate standard error $(n=4)$ 


\section{Leaves}

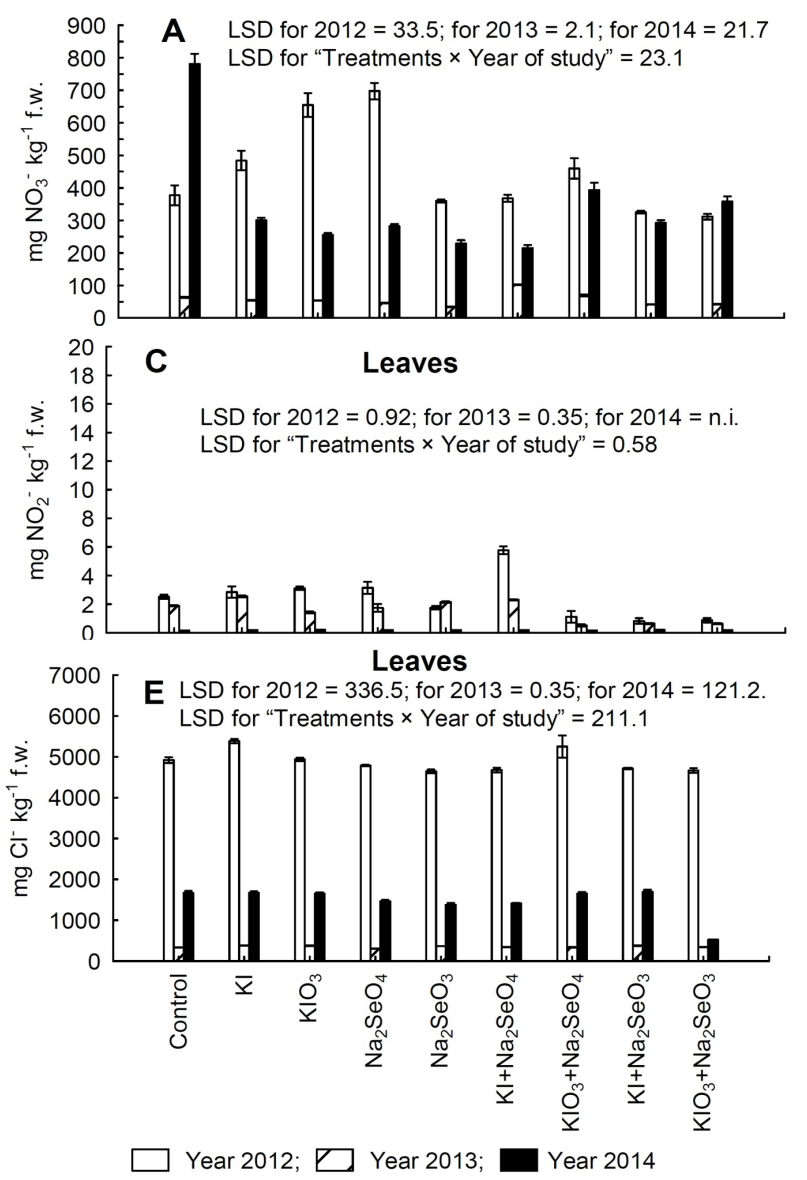

Roots

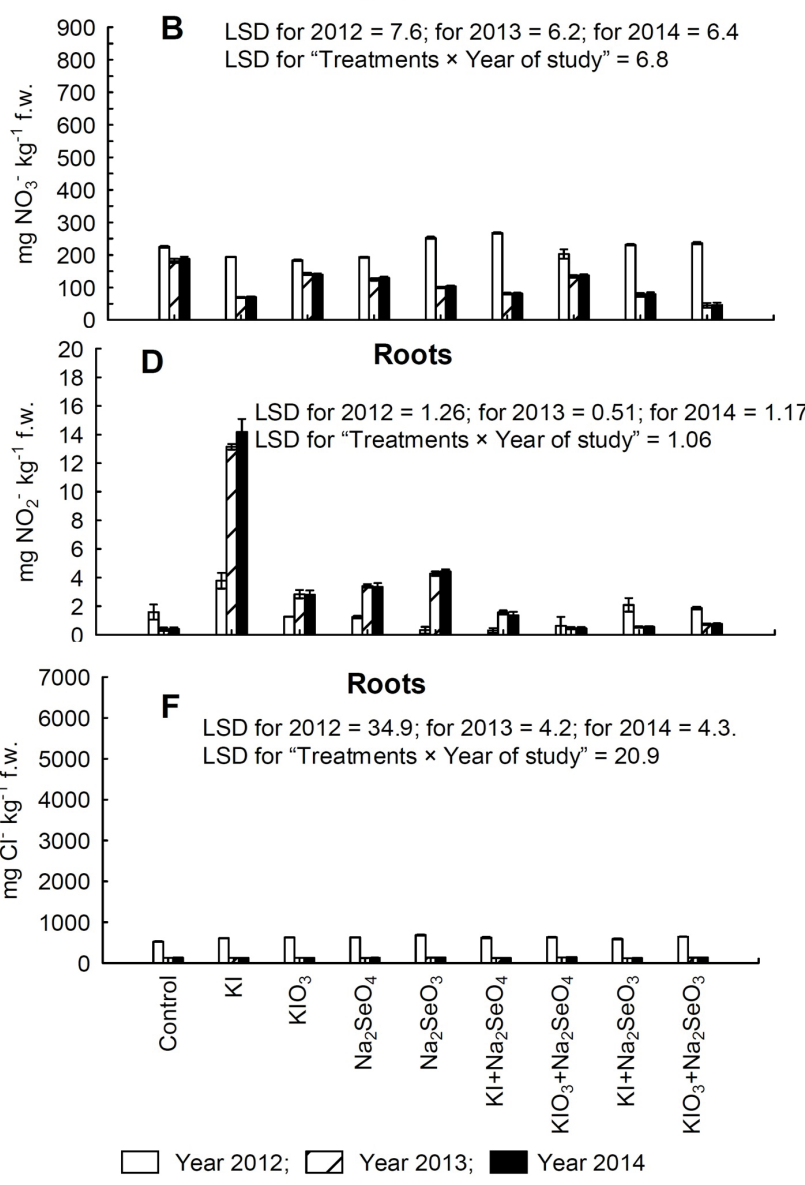

Figure 3. Content of nitrates (V) (A and B), nitrates (III) (C and D) and chlorides (E and F) in leaves (A, C and E) and storage roots (B, D and F) in each year of the study (2012-2014) depending on the applied I and Se fertilization. Bars indicate standard error $(n=4)$

to be underlined that plant tolerance to selenates (IV) and selenates (VI) strongly depends on the cultivation system, whether hydroponics or in the field, with complex processes of sorption occurring in the latter (Ríos et al. 2010, Hawrylak-Nowak et al. 2015, Smoleń et al. 2015, 2016a). Also in the case of iodine, carrot is far more tolerant to high doses of this element than other vegetable species, including spinach, pak choi and celery (Dai et al. 2004).

\section{The content of nitrates (III), nitrates (V), chlorides, oxalates and citrates in carrot plants}

The content of nitrates (III), nitrates (V), chlorides, oxalates and citrates in carrot leaves and roots was significantly affected by the tested factors, with the exception of nitrate (III) level in leaves in 2014 (Fig. 3 A-F and Fig. 4 A-D). Various weather conditions occurring during carrot cultivation contributed, however, todiversequantitativerelations between combinations regarding these parameters a significant 'treatments $\times$ year of study' interaction (Fig. 3 A-F and Fig. 4 A-D).
Generally, a higher content of nitrates (V) and chlorides was found in leaves than in roots, while the latter organs were characterized by an increased accumulation of nitrates (III). With respect to oxalates and citrates, their content remained at the same level in both leaves and roots (Fig. 3 A-F and Fig. 4 A-D). In each year of the study, adverse effects of the applied iodine and selenium were revealed with respect to the leaf content of nitrates (V) as well as leaf and carrot levels of nitrates (III) and chlorides in individual combinations of the study.

Studies on protein isolates revealed that iodate form of iodine $\left(\mathrm{IO}_{3}^{-}\right)$can be an alternative electron acceptor for nitrate reductase (NR) enzyme (Barber and Notton 1990). We did not find any clear effect of soil fertilization with I and Se on the nitrate (V) content in plants. In other words, iodine application in the form of $\mathrm{IO}_{3}^{-}$did not contribute to excessive accumulation of these ions in plant tissues. Such a relationship was previously proposed based on the findings of marine algae studies, suggesting the 

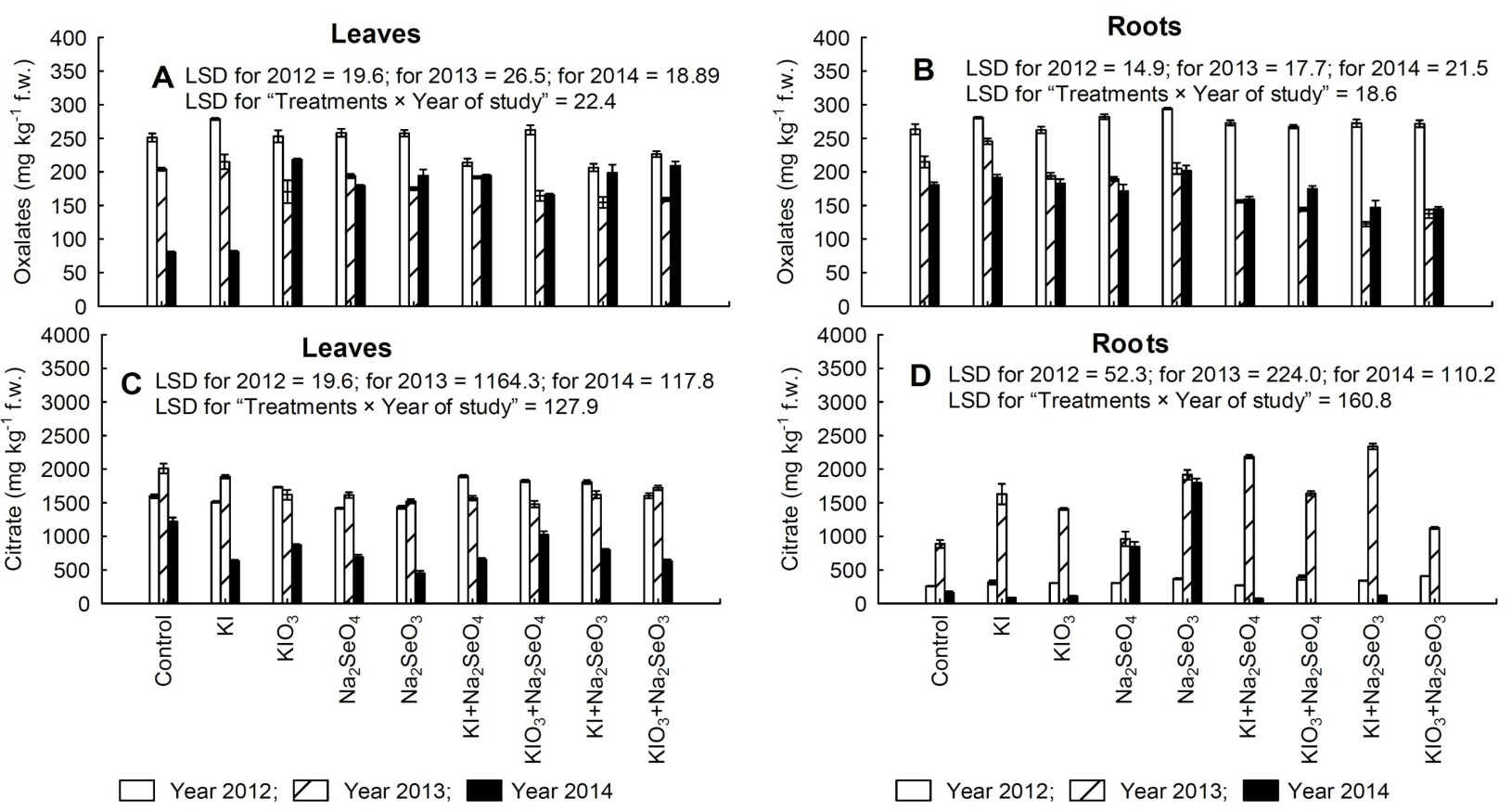

Figure 4. Content of oxalates (A and B) and citrates $(C$ and $D)$ in leaves (A and C) and storage roots $(B$ and $D)$ in each year of the study (2012-2014) depending on the applied I and Se fertilization. Bars indicate standard error $(n=4)$

participation of nitrate reductase in $\mathrm{IO}_{3}^{-}$reduction to $\mathrm{I}^{-}$(Hung et al. 2005). According to these authors, $\mathrm{IO}_{3}^{-}$application weakens the process of nitrate reduction, leading to excessive accumulation of nitrates (V). The lack of a clear relationship between the application of $\mathrm{KIO}_{3}$ (alone or together with selenium) on nitrate (V) content, observed in the present study, could have been caused by $\mathrm{IO}_{3}{ }^{-}$reduction to the $\mathrm{I}_{2}$ or $\mathrm{I}^{-}$that occurs in the soil (Ashworth et al. 2003, Yuita et al. 2005, Ashworth and Shaw 2006) or root surface, as found in rice plants (Kato et al. 2013). Generally, the content of nitrates (III) in vegetables remains at a very low level - below $5 \mathrm{mg} \mathrm{NO}_{2}^{-} \mathrm{kg}^{-1}$ (Tamme et al. 2006) - and increases during improper post-harvest and post-production storage (Nabrzyski and Gajewska 1993). In comparison to the control, an increase of the content of nitrates (III) in the roots of carrots fertilized with $\mathrm{KI}, \mathrm{KIO}_{3}, \mathrm{Na}_{2} \mathrm{SeO}_{3}, \mathrm{Na}_{2} \mathrm{SeO}_{4}$ was noticeable in the entire three-year period. On the other hand, simultaneous application of iodides and iodates with both selenium forms significantly lowered nitrate (III) accumulation in carrot roots when compared to the application of iodine (KI and $\left.\mathrm{KIO}_{3}\right)$ or selenium $\left(\mathrm{Na}_{2} \mathrm{SeO}_{3}\right.$ and $\left.\mathrm{Na}_{2} \mathrm{SeO}_{4}\right)$ alone (Fig. 3 D). Such relationships were not observed in the leaves (Fig. $3 \mathrm{C}$ ). In comparison to the control and other combinations, the highest content of nitrates (III) was noted in the storage roots of carrot fertilized with $\mathrm{KI}$ and exceeded $12 \mathrm{mg} \mathrm{NO}{ }^{-}$kg f.w. in 2013 and 2014 (Fig. 3 D).
These results indicate that the application of iodides (I) inhibited the reduction of $\mathrm{NO}_{2}^{-}$to $\mathrm{NH}_{4}^{+}$, which is controlled by nitrite reductase (NiR) - unlike the nitrate reductase (NR) enzyme responsible for $\mathrm{NO}_{3}^{-}$to $\mathrm{NO}_{2}^{-}$reduction. Basing on literature data, the direct physiological and biochemical causes of increased $\mathrm{NO}_{2}^{-}$accumulation after $\mathrm{KI}$ or $\mathrm{KIO}_{3}$ application cannot be established (Dai et al. 2004, Smoleń et. al 2011a,b, 2014b). Interestingly, in our study KI fertilization did not substantially affect the content of free amino acids in carrot storage roots. The biosynthesis of amino acids is indirectly dependent on the $\mathrm{NO}_{3}^{-}$reduction to $\mathrm{NH}_{4}^{+}$(through $\mathrm{NO}_{2}^{-}$). Ammonium cations are further assimilated in the GS-GOGAT cycle leading to the production of organic nitrogen compounds - amino acids (Blasco et al. 2010, 2011). In the studies conducted by Smoleń et al. (2011b), simultaneous application of $\mathrm{KI}$ with various nitrogen fertilizers $\left[\mathrm{Ca}\left(\mathrm{NO}_{3}\right)_{2}+\mathrm{KI}\right.$ or $\left.\left(\mathrm{NH}_{4}\right)_{2} \mathrm{SO}_{4}+\mathrm{KI}\right]$ decreased the level of $\mathrm{N}$-total in carrot storage roots (lower nitrogen nutrition status) as compared to respective combinations with $\mathrm{KIO}_{3}$ application $\left[\mathrm{Ca}\left(\mathrm{NO}_{3}\right)_{2}+\mathrm{KIO}_{3}\right.$ or $\left.\left(\mathrm{NH}_{4}\right)_{2} \mathrm{SO}_{4}+\mathrm{KIO}_{3}\right]$. Additionally, Smoleń et al. (2011b) indicate that iodine form ( $\left.\mathrm{I}^{-}\right)$impairs the nitrogen metabolism of plants to a greater extent than iodates $\left(\mathrm{IO}_{3}^{-}\right)$. Blasco et al. (2012) observed that increasing doses of $\mathrm{I}^{-}$ substantially decreased $\mathrm{N}$-total content on lettuce (in soilless cultivation), which was not noted for $\mathrm{IO}_{3}^{-}$application. On the other hand, Smolen et al. (2014a) did not reveal any influence of $\mathrm{KIO}_{3}$ and 
$\mathrm{Na}_{2} \mathrm{SeO}_{4}$ or $\mathrm{KIO}_{3}+\mathrm{Na}_{2} \mathrm{SeO}_{4}$ applied foliarly or through the nutrient solution on the level of nitrogen nutrition of lettuce leaves and roots. A mechanism of antagonistic action of the $\mathrm{I}^{-}$form of iodine on the uptake and metabolism of nitrogen $\left(\mathrm{NO}_{3}{ }^{-}\right.$and $\mathrm{NH}_{4}^{+}$) is yet to be described. Little information was given by Blasco et al. (2010, 2011). In their study, the application of $\mathrm{IO}_{3}^{-}$(as opposed to $\mathrm{I}^{-}$) stimulated $\mathrm{NO}_{3}{ }^{-}$reduction, enhanced $\mathrm{NH}_{4}^{+}$assimilation in the GS-GOGAT cycle and improved the process of photosynthesis in lettuce plants.

In that aspect, the observation of substantially reduced accumulation of $\mathrm{NO}_{2}^{-}$in carrot roots after the simultaneous application of $\mathrm{KI}$ with $\mathrm{Na}_{2} \mathrm{SeO}_{4}$ or $\mathrm{Na}_{2} \mathrm{SeO}_{3}$ as compared to $\mathrm{KI}$ applied alone is interesting. It may indicate that the presence of selenium at IV and VI oxidation states (and the products of their conversion) limits the inhibiting influence of iodides on the functioning of the NiR enzyme. In our studies, the application of KI and $\mathrm{KIO}_{3}$ similarly increased N-total content in carrot storage roots as compared to the control (detailed data concerning total nitrogen content is not presented). In leaves, the application of $\mathrm{KIO}_{3}$ increased the content of the $\mathrm{N}$-total to a greater extent than $\mathrm{KI}$ when compared to the control combination. In our previous studies, we did not note any significant influence of one-time pre-sowing fertilization with $\mathrm{KI}$ and $\mathrm{KIO}_{3}$ on nitrate (III) content in carrot (also cultivar Kazan $\mathrm{F}_{1}$ ) cultivated in a pot experiment (Smoleń et al. 2009). It can therefore be concluded that the effect of iodine fertilization on nitrate (III) accumulation or N-total content in carrot plants strongly depends on the cultivation method but also on iodide availability to plants. In the case of topdressing application of KI (as tested in our study), it could have been greater than that of one-time presowing introduction (Smoleń et al. 2009, 2011a, b).

The content of oxalates and citrates in plants is related to calcium nutrition. Carrot and other species from the Apiaceae family are characterized by a low content of oxalates (Wińska-Krysiak 2006). The level of citrate synthase expression (formally the first enzyme in that cycle, responsible for the formation of citrate) is directly dependent on the growth of carrot cells (Koyama et al. 1999). The accumulation of citrates in carrot is correlated with the $\mathrm{H}^{+}$efflux, possibly resulting from the action of $\mathrm{H}^{+}$-ATPase located on the plasma membrane (Ohno et al. 2003). In 2012, a lower content of calcium was noted in carrot roots than in 2013 and 2014 (of 0.052 and $0.030 \mathrm{Ca} \%$ d.w, respectively - detailed data not presented). The problems related to calcium uptake by plants could have impaired water balance in plants as $\mathrm{Ca}^{2+}$ cations, along with $\mathrm{K}^{+}$, play an important role in plant cell osmoregulation. In 2012, which had a lower amount of rainfall and higher air temperature than in 2013-2014, relatively higher contents of nitrates $(\mathrm{V})$, chlorides and oxalates were noted in carrot leaves and roots as well as of nitrates (III) in leaves as compared to the other years of the study (Fig. 3 A, B, C, E, F and Fig. 4 A-B). A shortage of water in soil might have contributed to such results, more negatively affecting metabolic processes (related to cell respiration) in storage roots rather than leaves. It is substantiated by much lower contents of calcium and citric acid (a basic compound of the Krebs cycle) in roots in 2012 than in 2013-2014. However, no such relationships were observed in the leaves (Fig. $4 \mathrm{C}$ and D).

The content of oxalates (White and Broadley 2009) and citrates (Eticha et al. 2010) is genotypedependent. Jaworska and Kmiecik (1999) revealed that the concentration of total and soluble oxalates in spinach and New Zealand spinach is strongly related to climatic conditions throughout the cultivation period, however. Smoleń et al. (2016b) observed that oxalate and citrate levels in lettuce were substantially modified by soil and climate conditions in individual years rather than the applied iodine and selenium fertilization. The results obtained in the present study also indicate that the contents of the aforementioned compounds in carrot leaves and roots was affected more by such conditions than the tested combinations. The lack of an unequivocal influence of I, Se as well as $\mathrm{I}+$ Se fertilization on the oxalate content in carrot plants needs to be considered as a positive outcome, however. According to White and Broadley (2009), plant biofortification with mineral elements should increase the content of nutraceutics, simultaneously limiting the accumulation of antinutrients such as oxalates, polyphenolics (tannins) or phytates in crops.

\section{The content of sugars in carrot storage roots}

A statistically significant effect of the tested combinations with iodine and selenium fertilization was noted with respect to the content of glucose, fructose, sucrose and total sugars in carrot storage roots - also a significant 'treatments $\times$ year of study' interaction of these parameters was observed (Fig. 5 A-D). In 2014 a significantly higher content of glucose, fructose and total sugars was noted in carrots from all combinations (with the exception of $\mathrm{KIO}_{3}+\mathrm{Na}_{2} \mathrm{SeO}_{4}$ ) when compared to the years 

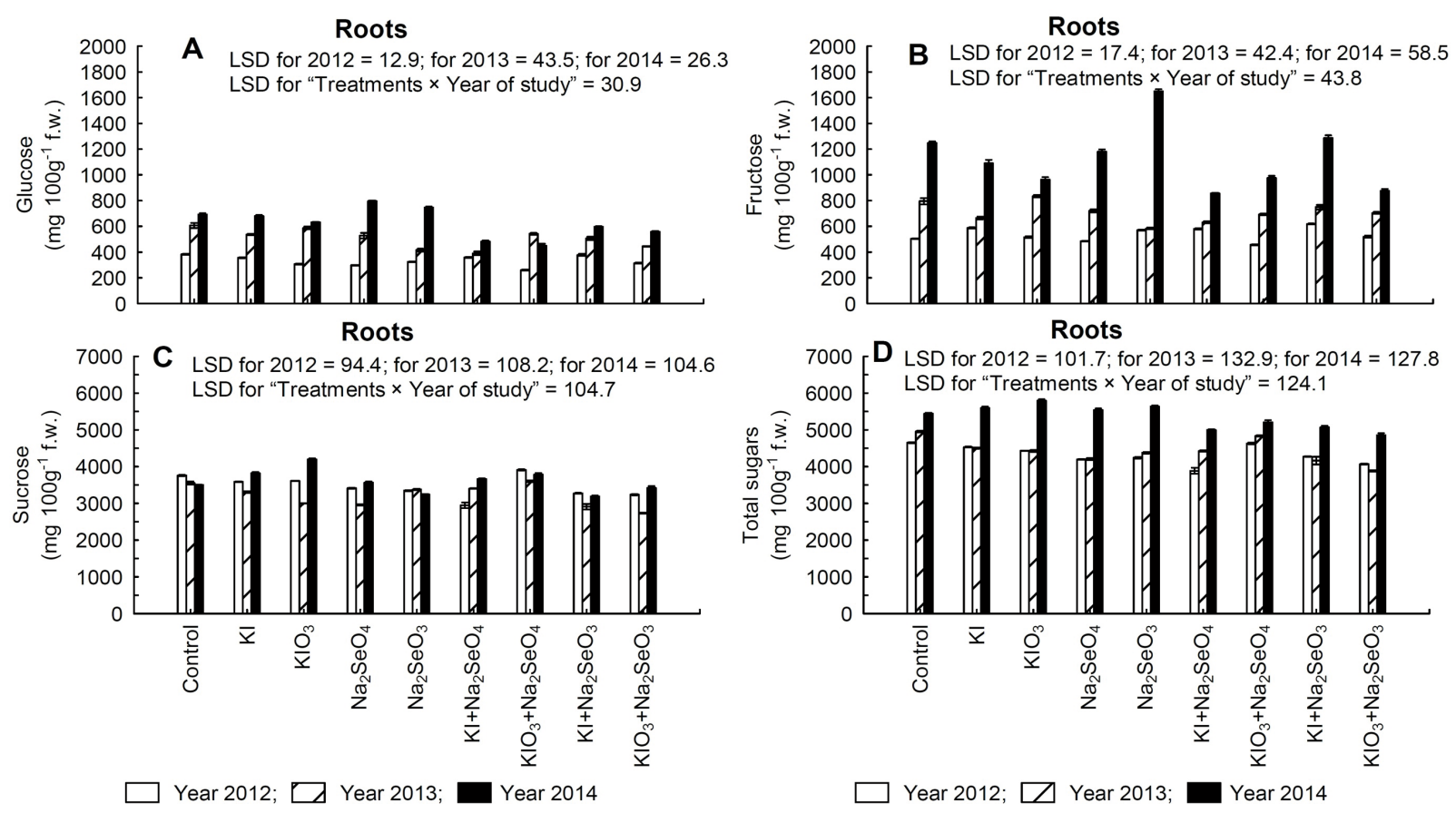

Figure 5. Content of glucose (A), fructose (B), sucrose $(C)$ and total sugars (the sum of the three $-\mathrm{D}$ ) in storage roots in each year of the study (2012-2014) depending on the applied I and Se fertilization. Bars indicate standard error $(n=4)$

2012 and 2013. Most likely, it was favoured by the most evenly distributed rainfall (followed by optimal soil humidity) as well as PAR and temperature values noted in that year. In 2012 and 2013 a significant decrease in the content of sucrose and total sugars was observed in all combinations when compared to the control, with the exception of carrots fertilized with $\mathrm{KIO}_{3}+\mathrm{Na}_{2} \mathrm{SeO}_{4}$ Among all of the analysed sugars, the most similar values within the three years of the study were found for sucrose, irrespective of diverse weather conditions (Fig. 5 C).

Each year, soil fertilization with $\mathrm{KI}+\mathrm{Na}_{2} \mathrm{SeO}_{4}$ reduced the content of glucose and total sugars in carrot as compared to the control and other combinations (Fig. $5 \mathrm{~A}$ and D). It additionally lowered the accumulation of sucrose (in 2012, Fig. 5 C) and fructose in roots (in 2014, Fig. 5 B). It needs to be underlined that, irrespective of the year, simultaneous application of $\mathrm{Na}_{2} \mathrm{SeO}_{4}$ with $\mathrm{KIO}_{3}$ contributed to a significant increase of sucrose content, while the total concentration of sugars in carrot roots remained at a level comparable to the control (Fig. $5 \mathrm{C}$ and D). In the remaining combinations with iodine and selenium application (apart from $\mathrm{Na}_{2} \mathrm{SeO}_{4}+\mathrm{KI} / \mathrm{KIO}_{3}$ ), diverse effects ('in plus' or 'in minus') were noted with respect to the content of tested sugars in roots (Fig. 5 A-D). In other studies conducted according to the same experimental design by Smoleń et al. (2015), simultaneous application of $\mathrm{Na}_{2} \mathrm{SeO}_{4}$ with KI significantly decreased sucrose content in lettuce, while fertilization with the same Se form applied with $\mathrm{KIO}_{3}$ increased it. This observation, therefore, confirms the possibility of obtaining diverse plant reactions, with respect to sugar accumulation, depending on the iodine form when applied together with selenates (VI).

\section{Other quality parameters of carrot storage roots}

The nutritional and health-promoting quality of carrot storage roots is affected by numerous endoand exogenous factors (Suojala 2000), as well as on the cultivar and harvest date (Gajewski et al. 2009b, Szymczak et al. 2009). Exogenous factors occurring during the cultivation, particularly climatic (Rosenfeld et al. 1998a,b,c), soil and agro-technical ones have a substantial effect on the growth, shape and size of storage roots along with their chemical composition (Suojala 2000, Gajewski et al. 2009a, 2010).

In each year of the study, a significant but diverse influence of applied iodine and selenium fertilization was observed with respect to the contents of dry matter, free amino acids and carotenoids in carrot (Fig. $6 \mathrm{~A}, \mathrm{~B}$ and $\mathrm{C}$ ). In one or two years of the experiment, the tested factors significantly affected the level of phenolic compounds (in 2012 and 2013, Fig. 6 E), phenylpropanoids (in 2013, Fig. 6 F) and flavonols (in 2012, Fig. 6 G), as well as free radical scavenging activity (DPPH, in 2013, Fig. 6 D). 

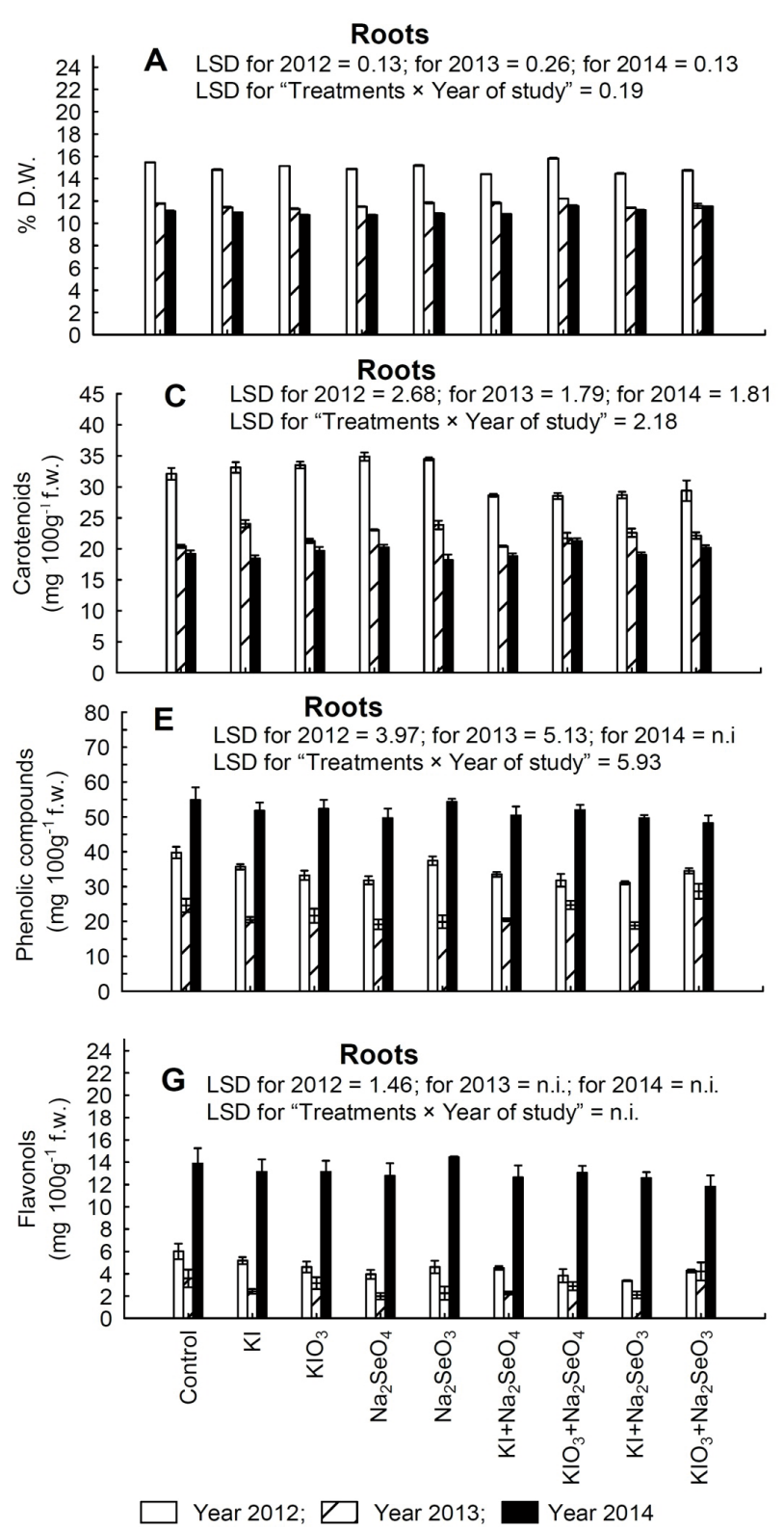

Roots

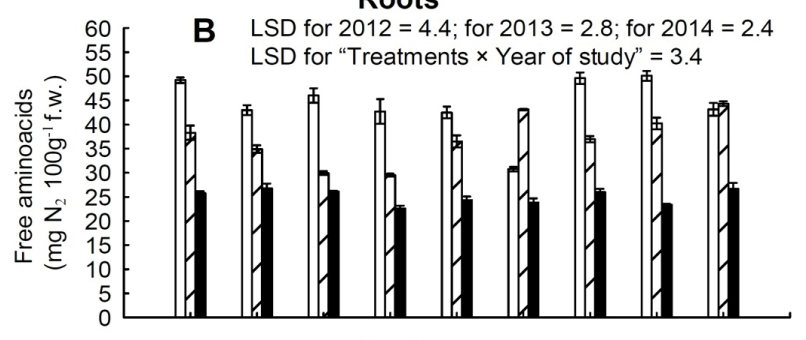

Roots

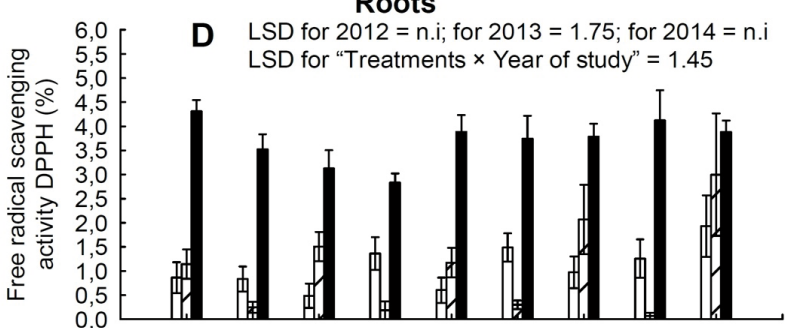

Roots

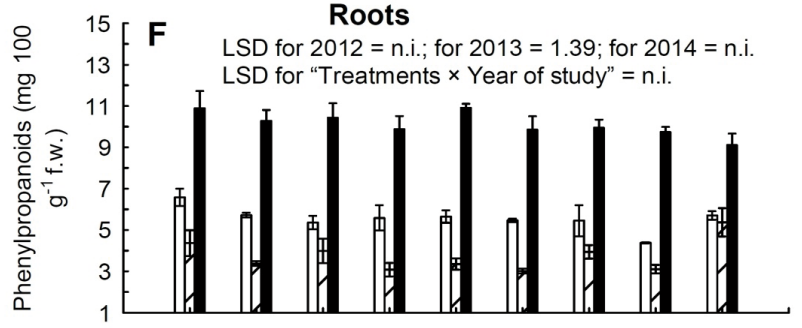

Roots

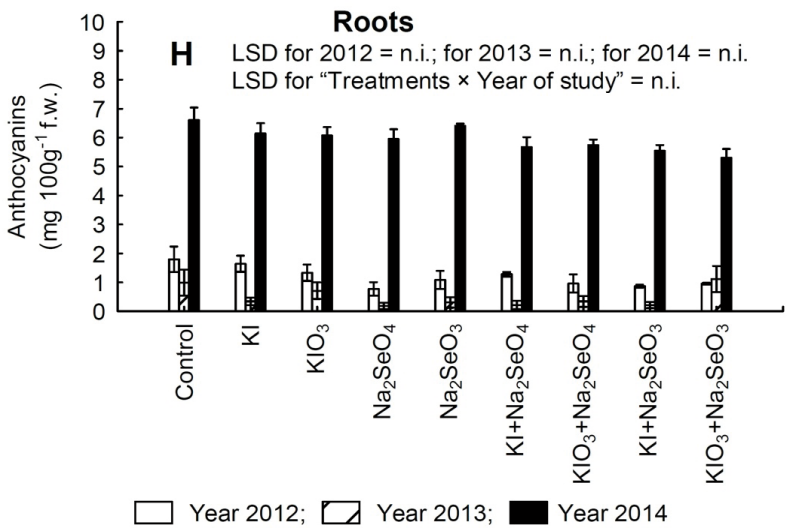

Figure 6. Content of dry weight (A), free amino acid (B), carotenoids (C) and free radical scavenging activity (DPPH) (D) as well as the content of phenolic compounds (E), phenylpropanoids (F), flavonols (G) and anthocyanins (H) in storage roots in each year of the study (2012-2014) depending on the applied I and Se fertilization. Bars indicate standard error $(n=4)$

Among the described quality parameters, a statistically significant 'treatments $\times$ year of study' interaction was noted for the contents of dry matter, free amino acids, carotenoids and phenolic compounds as well as on the free radical scavenging activity of carrot storage roots (Fig. 6 A-E). The content of anthocyanins in carrot was in no case affected by the tested factors, as well as the 'treatments $\times$ year of study' interaction (Fig. $5 \mathrm{H}$ ). The content of phenylpropanoids and flavonols (Fig. $6 \mathrm{~F}$ and $\mathrm{G}$ ) in carrot roots did not vary significantly between the combinations within the entire period of the study (Fig. 6 F and G).
Gajewski et al. (2011) indicated that a diminished amount of PAR radiation lowers the quality of carrot storage roots, mainly by a significant increase of nitrate (V) accumulation and a decrease in dry matter, soluble solids and $\beta$-carotene contents. The proposed relationships were, however, strongly dependent on other weather parameters. Our studies revealed a significant increase in the contents of dry matter, free amino acids and carotenoids in carrot roots cultivated in the year with the lowest amount of rainfall in the summer months and much higher PAR radiation (2012, Fig. 6 A, B and C). On the other hand, carrots grown in 2014 (with the most 
optimal weather conditions for their cultivation) were characterized by substantially higher levels of phenolic compounds, phenylpropanoids, anthocyanins and free radical scavenging activity (DPPH) as compared to the years 2012 and 2013 (Fig. 6 D-H).

Analysing the influence of soil fertilization with iodine and selenium compounds on the described quality parameters of carrot, a significant decrease of carotenoid content in plant roots fertilized simultaneously with iodine and selenium was clearly distinguished in 2012 when compared to its separate application (Fig. 6 C). Additionally, a significant increase of free radical scavenging activity (DPPH) was observed after simultaneous introduction of iodine and selenium as compared to fertilization with $\mathrm{KI}, \mathrm{KIO}_{3}, \mathrm{Na}_{2} \mathrm{SeO}_{3}$ and $\mathrm{Na}_{2} \mathrm{SeO}_{4}$ alone (Fig. 6 D). However, these relationships were not revealed in other years of the study. Taking the above into account, it can be assumed that the values of the parameters in carrot cultivated in 20122013 and described in this subchapter depended to a greater degree on the soil and weather conditions than on the applied fertilization with iodine and selenium.

Smoleń et al. (2015) revealed that soil fertilization with $\mathrm{Na}_{2} \mathrm{SeO}_{4}, \mathrm{KI}+\mathrm{Na}_{2} \mathrm{SeO}_{4}$ and $\mathrm{KIO}_{3}+\mathrm{Na}_{2} \mathrm{SeO}_{4}$ induced a stress response in lettuce plants, reflected as decreased head weight and sugar content (except for $\mathrm{Na}_{2} \mathrm{SeO}_{4}$ applied alone) accompanied by an increased level of phenolic compounds, phenylpropanoids, flavonols and antioxidant activity. Accumulation of phenolic compounds in plants is described as one of the mechanisms of plant reaction to biotic and abiotic stress factors (Michalak 2006, Korkina 2007), including high selenium (Ríos et al. 2008) and iodine doses (Blasco et al. 2010). In terms of plant physiology and biochemistry, no clear and unequivocal effect of the tested I, Se and I + Se fertilization on the described quality parameters of carrot storage roots can be considered positive. It confirms the lack of a strong negative impact and toxicity of iodine and selenium (applied in relatively high doses) to carrot biomass and chemical composition that characterizes its quality. Importantly, it was observed even despite a substantial increase of I and Se content in carrot plants - detailed data presented in the publication by Smoleń et al. (2016a).

\section{CONCLUSIONS}

1. Despite diverse weather conditions in each year of the study, no significant influence of iodine and selenium application was found with respect to average weight of a single root and leaf yield from one carrot plant.

2. The influence of the simultaneous application of selenates and iodine on sugar accumulation in carrot storage roots depended on the chemical form of iodine.

3. Only in the case of nitrite (III) accumulation was a clear effect of iodine and selenium interaction revealed and noted in all three years of the study. It was manifested by a significant decrease in its content in storage roots after simultaneous fertilization with iodine and selenium as compared to the application of each of the elements alone.

\section{FUNDING}

This work was financed by the Polish National Science Centre - grant no. DEC-2011/03/D/ NZ9/05560 'I and Se biofortification of selected vegetables, including the influence of these microelements on yield quality as well as the evaluation of iodine absorption and selected biochemical parameters in rats fed with vegetables biofortified with iodine' planned for 2012-2015.

\section{AUTHOR CONTRIBUTIONS}

S.S. - designed and supervised the experiment, analysed and discussed the results, wrote the manuscript; Ł.S. - supervised the field cultivation of carrot, performed analyses using a ICP-OES spectrometer, helped with manuscript preparation; I.L.-S. - performed statistical analyses, helped with manuscript preparation; R.R. - conducted field cultivation and chemical analyses using capillary electrophoresis; M.L.-S. - performed chemical analysis using the HPLC technique, helped with manuscript preparation; A.K., E.P., R.B.-K., A.K., J.K.-D. - performed the experiment, consulted and corrected the manuscript; W.S. - designed the general idea of the project, helped with manuscript preparation.

\section{CONFLICT OF INTEREST}

Authors declare no conflict of interest.

\section{REFERENCES}

Ashworth D.J., Shaw G., 2006. A comparison of the soil migration and plant uptake of radioactive chlorine and iodine from contaminated groundwater. J. Environ. Radioact. 89: 61-80. 
Ashworth D.J., Shaw G., Butler A.P., Ciciani L., 2003. Soil transport and plant uptake of radio-iodine from near-surface groundwater. J. Environ. Radioact. 70: 99-114.

Baranska M., Schulz H., Baranski R., Nothnagel T., Christensen L.P., 2005. In situ simultaneous analysis of polyacetylenes, carotenoids and polysaccharides in carrot roots. J. Agric. Food Chem. 53(17): 65656571.

Baranska M., Baranski R., Schulz H., Nothnagel T., 2006. Tissue-specific accumulation of carotenoids in carrot roots. Planta 224(5): 1028-1037.

Baranski R., Allender C., Klimek-Chodacka M., 2012. Towards better tasting and more nutritious carrots: Carotenoid and sugar content variation in carrot genetic resources. Food Res. Inter. 47(2): 182-187.

BArber M.J., Notton B.A., 1990. Spinach nitrate reductase - effects of ionic strength and $\mathrm{pH}$ on the full and partial 1. Enzyme activities. Plant Physiol. 93: 537-540.

Blasco A., Rios J.J., Cervilla L.M., SAnchezRodriguez E., Rubio-Wilhelmi M.M., Rosales M.A., et al., 2011a. Iodine application affects nitrogen-use efficiency of lettuce plants (Lactuca sativa L.). Acta Agric. Scand. 61(4): 378-383.

Blasco B., Rios J.J., Leyva R., Cervilla L.M., SanchezRodriguez E., Rubio-Wilhelmi, et al., 2010. Does iodine biofortification affect oxidative metabolism in lettuce plants? Biol. Trace Elem. Res. 142(3): 831842 .

Blasco B., Ríos J.J., Sánchez-Rodríguez E., RubioWilhelmi M.M., Leyva R., Romero L., Ruiz J.M., 2012. Study of the interactions between iodine and mineral nutrients in lettuce plants. J. Plant Nut. 35(13): 958-1969.

Bogdanov S., 2002. Harmonised methods of the International Honey Commission. Int. Honey Comm.: 1-62.

Cebulak T., Sady W., 2000. Effect of cultivation methods on nutritive compounds in the carrot. Folia Hort. 12(1): 77-84.

Dai J.L., Zhu Y.G., Zhang M., Huang Y.Z., 2004. Selecting iodine-enriched vegetables and the residual effect of iodate application to soil. Biol. Trace Elem. Res. 101: 265-276.

Eticha D., Zahn M., Bremer M., Yang Z., Rangel A.F., Rao I.M., Horst W.J., 2010. Transcriptomic analysis reveals differential gene expression in response to aluminium in common bean (Phaseolus vulgaris) genotypes. Ann. Bot. 105(7): 1119-1128.

Fakumoto L., Mazza G., 2000. Assessing antioxidant and prooxidant activities of phenolic compounds. J. Agric. Food Chem. 48(8): 3597-3604.

Gajewski M., Szymczak P., Bajer M., 2009a. The accumulation of chemical compounds in storage roots by carrots of different cultivars during vegetation period. Acta Sci. Pol., Hortorum Cultus 8(4): 69-78.
Gajewski M., Węglarz Z., Wereda A., Bajer M., Kuczkowska A., Majewski M., 2010. Carotenoid accumulation by carrot storage roots in relation to nitrogen fertilization level. Not. Bot. Hort. Agrobot. Cluj 38(1): 71-75.

Gajewski M., Szymczak P., Bajer M., Sereda A., 2011. Accumulation of chemical compounds in carrot storage roots under different light conditions. Ann. Warsaw Univ. Life Sci. - SGGW, Horticult. Landsc. Architect. 32: 15-23.

Gajewski M., Węglarz Z., Sereda A., Bajer M., Kuczkowska A., Majewski M., 2009b. Quality of carrots grown for processing as affected by nitrogen fertilization and harvest term. Veg. Crop. Res. Bull. 70: 135-144.

GUS, 2005. Environment Protection Information and statistical analysis. Cent. Stat. Off. Pol. Wars. (in Polish).

Hawrylak-Nowak B., Matraszek R., Pogorzelec M., 2015. The dual effects of two inorganic selenium forms on the growth, selected physiological parameters and macronutrients accumulation in cucumber plants. Acta Physiol. Plant. 37: 41-54.

Hung C.C., Wong G.T.F., Dunstan W.M., 2005. Iodate reduction activity in nitrate reductase extracts from marine phytoplankton. Bull. Mar. Sci. 76(1): 61-72.

JAWORSKA G., KMIECIK W., 1999. Content of selected mineral compounds, nitrates III and V, and oxalates in spinach (Spinacia oleracea L.) and New Zealand spinach (Tetragonia expansa Murr.) from spring and autumn growing seasons. EJPAU 2(2). Available online at http://www.ejpau.media.pl/volume2/issue2 /food/art-03.html.

Kabata-Pendias A., 2011. Trace elements in soil and plants. Fourth Edition CRC Press, Taylor and Francis Gr.

Kato S., Wachi T., Yoshinira K., Nakagawa T., IshikaWa A., TAkagi D., et al., 2013. Rice (Oryza sativa L.) roots have iodate reduction activity in response to iodine. Front. Plant Sci. 4:227, http://dx.doi. org/10.3389/fpls.2013.00227.

Kopsell D.A., Kopsell D.E., 2007. Selenium. In: Handbook of Plant Nutrition. A.V. Barker and D.J Pilbeam (eds), CRC Press Taylor \& Francis Gr.

KorkinA L.G., 2007. Phenylpropanoids as naturally occurring antioxidants: From plant defense to human health. Cell. Mol. Biol. 53(1): 15-25.

Koyama H., Takita E., Kawamura A., Hara T., Shibata D., 1999. Over expression of mitochondrial citrate synthase gene improves the growth of carrot cells in Al-phosphate medium. Plant Cell Phys. 40(5): 482488.

Lawson P.G., Daum D., Czauderna R., Meuser H., HÄrtLing J.W., 2015. Soil versus foliar iodine fertilization as a biofortification strategy for fieldgrown vegetables. Front. Plant Sci. 6:450, doi: 10.3389/fpls.2015.00450. 
Longchamp M., Castrec-Rouelle M., Biron P., Bariac T., 2015. Variations in the accumulation, localization and rate of metabolization of selenium in mature Zea mays plants supplied with selenite or selenate. Food Chem. 182: 128-135.

Mao H., Wang J., Wang Z., Zan Y., Lyons G., Zou C., 2014. Using agronomic biofortification to boost zinc, selenium, and iodine concentrations of food crops grown on the loess plateau in China. J. Soil Sci. Plant Nut. 14 (2): 459-470.

Michalak A., 2006. Phenolic compounds and their antioxidant activity in plants growing under heavy metal stress. Pol. J. Environ. Stud. 15(4): 523-530.

NABRZYSki M., Gajewska R., 1993. The content of nitrates and nitrites in fruits, vegetables and other foodstuffs. Roczniki PZH 45(3): 167-180.

Ohno T., Koyama H., Hara T., 2003. Characterization of citrate transport through the plasma membrane in a carrot mutant cell line with enhanced citrate excretion. Plant Cell Physiol. 44(2): 156-162.

Pekkarinen S., Stockmann H., Schwarz K., Heinnonen M., Hopia A., 1999. Antioxidant activity and partitioning of phenolic acids in bulk and emulsified methyl linoleate. J. Agric. Food Chem. 47(8): 30363043.

Przybysz A., Wrochna M., Malecka-Przybysz M., Gawrońska H., Gawroński S.W., 2016. The effects of $\mathrm{Mg}$ enrichment of vegetable sprouts on $\mathrm{Mg}$ concentration, yield and ROS generation. J. Sci. Food Agric. 96: 3469-3476.

Quilitzsch R., Baranska M., Schulz H., Hoberg E., 2005. Fast determination of carrot quality by spectroscopy methods in the UV-VIS, NIR and IR range. J. Appl. Bot. Food Qual. 79(3): 163.

Rhew R.C., Østergaard L., Saltzman E.S., Yanofsky M.F., 2003. Genetic control of methyl halide production in Arabidopsis. Curr. Biol. 13: 1809-1813.

Ríos J.J., Rosales M.A., Blasco B., Cervilla L.M., Romero L., Ruiz J.M., 2008. Biofortification of Se and induction of the antioxidant capacity in lettuce plants. Sci. Hort. 116: 248-255.

Ríos J.J., Blasco B., Cervilla L.M., Rubio-Wilhelmi M.M., Rosales M.A., SÁnchez-Rodríguez, et. al., 2010. Nitrogen-use efficiency in relation to different forms and application rates of Se in lettuce plants. J. Plant Grow. Reg. 29: 164-170.

Rosenfeld H.J., SAmuelsen R.T., Lea P., 1998 a. Relationship between physical and chemical characteristic of carrots grown at northern latitudes. J. Hort. Sci. Biotech. 73(2): 265-273.

Rosenfeld H.J., Samuelsen R.T., Lea P., 1998b. The effect of temperature on sensory quality, chemical composition and growth of carrots (Daucus carota L.) I. Constant diurnal temperature. J. Hort. Sci. Biotech. 73(2): 275-288.

Rosenfeld H.J., Samuelsen R.T., Lea P., 1998c. The effect of temperature on sensory quality, chemical composition and growth of carrots (Daucus carota
L.) II. Constant diurnal temperatures under seasonal light regimes. J. Hort. Sci. Biotech. 73(5): 578-588.

Rożek S., Leja M., Wojciechowska R., 2000. Effect of differentiated nitrogen fertilization on changes of certain compounds in stored carrot roots. Folia Hort. 12(2): 21-34.

Sady W., Cebulak T., 2000. The effect of irrigation and cultivation methods on some mineral compounds in storage roots of the carrot. Folia Hort. 12(2): 35-41.

Smoleń S., RożeK S., Strzetelski P., Ledwożyw I., 2011a. Preliminary evaluation of the influence of soil fertilization and foliar nutrition with iodine on the effectiveness of iodine biofortification and mineral composition of carrot. J. Element. 16(1): 103-114.

Smoleń S., Sady W., Rożek S., Ledwożyw I., Strzetelski P., 2011b. Preliminary evaluation of the influence of iodine and nitrogen fertilization on the effectiveness of iodine biofortification and mineral composition of carrot storage roots. J. Element. 16(2): 275-285.

Smoleń S., Kowalska I., SAdy W., 2014a. Assessment of biofortification with iodine and selenium of lettuce cultivated in the NFT hydroponic system. Sci. Hort. 166: 9-16.

Smoleń S., SAdy W., Ledwożyw-Smoleń I., Strzetelski P., Liszka-Skoczylas M., Rożek S., 2014b. Quality of fresh and stored carrots depending on iodine and nitrogen fertilization. Food Chem. 159: 316-322.

Smoleń S., Sady W., Strzetelski P., Rożek S., Ledwożyw I., 2009. The effect of iodine and nitrogen fertilization on quantity and quality of carrot yield well as on biological quality carrot. Envir. Prot. Nat. Resourc. 40: 286-292 (in Polish with English abstract).

Smoleń S., Skoczylas Ł., Rakoczy R., LedwożywSmoleń I., Liszka-Skoczylas M., Kopeć A., et al., 2015. Selected aspects of nitrogen metabolism and quality of field-grown lettuce (Lactuca sativa L.) depending on the diversified fertilization with iodine and selenium compounds. Acta Sci. Pol., Hortorum Cultus 14(5): 159-175.

Smoleń S., Skoczylas Ł., Ledwożyw-Smoleń I., Rakoczy R., Kopeć A., Piątkowska E., Bieżanowska-Kopeć R., et al., 2016a. Biofortification of carrot (Daucus carota L.) with iodine and selenium in a field experiment. Front. Plant Sci. 7:730. doi: 10.3389/ fpls.2016.00730

Smoleń S., Skoczylas Ł., Ledwożyw-Smoleń I., Rakoczy R., Kopeć A., Piątkowska E., Bieżanowska-Kopeć R., et al., 2016b. Iodine and selenium biofortification of lettuce (Lactuca sativa L.) by soil fertilization with various compounds of these elements. Acta Sci. Pol., Hortorum Cultus 15(5): 69-91.

Suojala T., 2000. Pre- and postharvest development of carrot yield and quality. University Of Helsinki Department of Plant Production. Section of Horticulture. Publication 37. Academic Dissertation.

Szymczak P., Gajewski M., Radzanowska J., DąBrowska A., 2007. Sensory quality and consumer liking of 
carrot cultivars of different genotype. Veg. Crops Res. Bull. 67: 163-176.

Tamme T., Reinik M., Roasto M., Juhkam K., Tenno T., KIIS, A., 2006. Nitrates and nitrites in vegetables and vegetable-based products and their intakes by the Estonian population. Food Addit. Contam. 23(4): 355-361.

White P.J., Broadley M.R., 2009. Biofortification of crops with seven mineral elements often lacking in human diets - iron, zinc, copper, calcium, magnesium, selenium and iodine. New Phytol. 182(1): 49-84.

Winkel L.H., VRiens B., Jones G.D., Schneider L.S., Pilon-Smits E., Bañuelos G.S., 2015. Selenium cycling across soil-plant-atmosphere interfaces: a critical review. Nutr. 7(6): 4199-4239.

WiŃSKA-KRYSIAK M., 2006. Calcium transporters in plants. Acta Agrophys. 7(3): 751-762 (in Polish with English abstract).

Yuita K., Kihou N., Yabusaki S., Takahashi Y., Saitoh T., Tsumura A., et al., 2005. Behavior of iodine in a forest plot, an upland field and a paddy field in the upland area of Tsukuba, Japan. Iodine concentration in precipitation, irrigation water, ponding water and soil w Water to a depth of $2.5 \mathrm{~m}$. Soil Sci. Plant Nutr. 51: 1011-1021.

ZhaO Y.Q., Zheng J.P., YAng M.W, YAng G.D, Wu Y.N., Fu F.F., 2011. Speciation analysis of selenium in rice samples by using capillary electrophoresisinductively coupled plasma mass spectrometry. Talanta 84: 983-988.

Zhu Y.G., Huang Y., Hu Y., Liu Y., Christie P., 2004. Interactions between selenium and iodine uptake by spinach (Spinacia oleracea L.) in solution culture. Plant Soil 261: 99-105.

Zhu Y. G., Pilon-Smits E. A., Zhao F. J., Williams P. N., Meharg A.A., 2009. Selenium in higher plants: understanding mechanisms for biofortification and phytoremediation. Trends Plant Sci. 14(8): 436-442.

Received February 17, 2016; accepted July 6, 2016 